\title{
Quando a lamentação leva à adesão: o Twitter enquanto suporte para a construção do ethos discursivoi
}

\begin{abstract}
Albylene da Silva*
Resumo: Sabendo que as postagens em meio digital elaboram novas formas de comunicação, Castells (2003) pontua que tais enunciados pressupõem comunidades virtuais. A partir disso, suscitam-se também imagens de si chamadas de ethos. Neste contexto, muitos dos ethé não correspondem a imagens positivas, sendo assim pouco analisados pelo aporte teórico deste trabalho - a Análise do Discurso Francesa. Considerando essas reflexões, propomos discutir aqui a construção do ethos discursivo em postagens pessoais no Twitter. Constatamos que, mesmo deslocados de sua concepção clássica, os ethé analisados levam os leitores a aderir a determinados discursos.
\end{abstract}

Palavras-chave: Postagens. Ethos discursivo. Twitter.

Abstract: Knowing that posts in digital media elaborate new forms of communication, Castells (2003) points out that these statements create virtual communities. In turn, that raises images of itself named ethos. In this context, many of the ethé are not shown in positive images, thus being little analyzed by the theoretical report of this work - the French Discourse Analysis. By these reflections, we discuss the construction of the discursive ethos in personal posts on Twitter. We found that, even when displaced from their classic conception, the ethé analyzed lead readers to adhere certain discourses.

Keywords: Posts. Discursive ethos. Twitter.

Resumen: Sabiendo que las publicaciones en los medios digitales crean nuevas formas de comunicación, Castells (2003) señala que tales declaraciones presuponen comunidades virtuales. A partir de esto, surgen imágenes de sí mismos llamados ethos. En este contexto, muchos de los ethé no corresponden a imágenes positivas, por lo que poco se analizan por la contribución teórica de este trabajo: el Análisis del Discurso Francés. Considerando estas reflexiones, proponemos discutir aquí la construcción del ethos discursivo en publicaciones personales en el Twitter. Descubrimos que, a pesar de estar desplazados de su concepción clásica, el ethé analizado conduce a los lectores a adherirse a ciertos discursos.

Palabras clave: Publicaciones. Ethos discursivo. Twitter.

\footnotetext{
${ }^{i}$ Este trabalho é um recorte do trabalho de conclusão do curso Letras Português e Inglês da Universidade Federal Rural de Pernambuco, Unidade Acadêmica de Garanhuns (UFRPE/UAG).

* Mestranda em Linguística pela Universidade Federal de Pernambuco (UFPE). http://orcid.org/ooooooo2-1781-1622 / E-mail: albylenesilva@yahoo.com.br
}

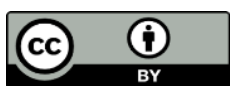

Este artigo está licenciado sob forma de uma licença Creative Commons Atribuição 4.0 Internacional, que permite uso irrestrito, distribuição e reprodução em qualquer meio, desde que a publicação original seja corretamente citada. 


\section{Introdução}

De acordo com Castells (2003), a partir da Internet, formam-se comunidades virtuais que culminam em novos padrões de relações sociais e que, além disso, tomam o lugar das formas de interação humana baseadas em limites territoriais. Essa nova forma de interação implica ainda na elaboração de identidades falsas e representações de papéis. A partir dessa perspectiva, a Internet foi tomada como um impulsionador de fantasias online, que leva, consequentemente, a uma fuga da realidade.

A constituição destes sujeitos nos meios digitais também leva Castells (2003) a afirmar que a Internet representa uma extensão da vida "real". Não obstante, acreditamos que, mesmo na criação de papéis, o sujeito que utiliza tais ferramentas estará mostrando uma parte de si. Baym (1998 apud CASTELLS, 2003, p. 100), por sua vez, atesta que "a realidade parece ser que muitos, provavelmente a maioria, dos usuários sociais da comunicação mediada por computador criam personalidades on-line compatíveis com suas identidades off-line”.

A representação de papéis aparece frequentemente em nossos dados, uma vez que o fenômeno discursivo ethos, como Maingueneau (2008a, 2008b, 2010, 2013, 2015) e Amossy (2005) apontam, implica a construção de uma imagem para si. Muitas vezes, a imagem elaborada não corresponde em total à realidade empírica do sujeito social. Ainda assim, embora represente uma pequena parte dos sujeitos usuários da Internet, correspondendo a adolescentes em sua maioria (CASTELLS, 2003), acreditamos ser importante analisar esta parcela que constrói imagens de si baseando-se em papéis e imagens discursivisadas e que, para tanto, fazem uso de mídias digitais.

Em adição, salientamos que a importância da nossa pesquisa também está vinculada à afirmação de Silva (2014, p. 84): "a maioria dos autores contemporâneos foca apenas a benevolência e a virtuosidade que Aristóteles prevê como necessárias ao ethos". Assim, muitos tipos de ethé são desconsiderados, bem como os diferentes aspectos que levam o público a aderir esses discursos. 
Portanto, ao selecionar o microblog Twitter, que tem seu público constituído, em sua maioria, no Brasil, por usuários de 21 a $44 \operatorname{anos}^{1}$, definimos como objetivo geral de nossa pesquisa analisar os tipos de ethé construídos no Twitter, bem como seus efeitos de sentido em perfis e postagens pessoais do microblog.

Além disso, a partir dos pressupostos teóricos da Maingueneau (2015, 2013, 2010, 2008a, 2008b), Amossy (2005), Castells (2003) e Recuero (2009), traçamos como objetivos específicos: i) avaliar de que maneira o comportamento dos jovens da atualidade pode relacionar-se aos tipos de ethé constatados em nossas análises; ii) verificar como tais constatações influenciam a constituição destes sujeitos.

Deste modo, nosso corpus é constituído por publicações coletadas por captura de tela entre outubro de 2015 e fevereiro de $2016^{2}$, visto que os dados fazem parte de meu trabalho de conclusão de curso, defendido em 2017. Ademais, foram selecionados os tuítes que: i) fazem referência ao próprio Twitter; e ii) se referem a ações cotidianas e sentimentos dos usuários do site. Assim, elaboramos uma pesquisa de abordagem predominantemente qualitativa (CRESWELL, 2007; BOGDAN; BIKLEN, 1994) utilizando o método indutivo (XAVIER, 2014).

Nesse contexto, adotamos a concepção de investigação qualitativa enquanto abordagem descritiva e que se volta para o próprio processo e não para os produtos finais, como vê-se, por outro lado, na investigação quantitativa (BOGDAN; BIKLEN, 1994). Além disso, entendemos a abordagem qualitativa como interpretativa e exploratória (CRESWELL, 2007), uma vez que há nela a intenção de solucionar problemas como, por exemplo, a imaturidade de um conceito, seja pela carência de teoria e de pesquisas anteriores, seja por possíveis imprecisões da teoria já existente ou, ainda, pela escassez de exploração e/ou descrição de determinado fenômeno.

\footnotetext{
${ }^{1}$ Relatório disponível em https://amplificadigital.com.br/blog/qual-o-perfil-dos-usuarios-em-cada-redesocial-no-brasil/\#: :text=Twitter\%3A,entre\%2021\%20a\%2044\%20anos. Acesso em: 10 mar. 2021.

${ }^{2}$ Em minha dissertação, A construção de identidade a partir do ethos discursivo em perfis temáticos no Twitter (em desenvolvimento), tenho atualizado minhas investigações ao comparar o engajamento de publicações de perfis temáticos nos anos de 2015 e 2016 e no ano de 2020. Já é possível constatar que, mesmo com o espaço temporal determinado, as publicações selecionadas ainda são reproduzidas tanto por perfis pessoais quanto por perfis temáticos, o que comprova, dentre outras conclusões, a permanência e recorrência do ethos de tristeza no Twitter.
} 
Quanto à coleta de dados, seguimos o método indutivo (XAVIER, 2014), pois partimos de observações, e não de hipóteses. Sendo assim, observamos o fenômeno do ethos dentro do campo de coleta (para nós, o Twitter) ao verificar a recorrência de tuítes de perfis pessoais que versam sobre a rede social e sobre ações cotidianas e sentimentos dos próprios usuários do site e, apenas posteriormente, elaboramos nossas conclusões. Como afirmam Bogdan e Biklen (1994), os investigadores qualitativos tendem a utilizar a indução para abarcar a ampla ocorrência dos dados particulares em análise.

Em conclusão, faz-se necessário elucidar que não selecionamos perfis específicos e, sim, aqueles que se adequaram aos critérios explanados anteriormente. Não fizemos uso das tarjas pretas nos casos de perfis verificados (identificados por um ícone azul ao lado do nome do usuário), já que se tratam de perfis públicos e autênticos.

\section{O suporte Twitter}

Nesta seção, abordaremos brevemente a necessária diferenciação entre suporte e gênero. De acordo com Marcuschi (2008, p. 85), “o suporte é um locus físico ou virtual com formato específico que serve de base ou ambiente de fixação do gênero materializado como texto.”. Em outras palavras, o suporte é o espaço que suporta o gênero e permite que ele circule em ambientes diversos. Logo, não há neutralidade no suporte, uma vez que ele está diretamente relacionado ao gênero.

Maingueneau (1996 apud FERNANDES, 2010, p. 989) também reconhece a importância do suporte e salienta que este é "fundamental na emergência e na estabilização de um gênero, significando que eles em alguns gêneros determinam sua funcionalidade, ainda mais quando agregados ao uso de suportes gerados pela demanda tecnológica.".

Visto que o Twitter é o site em que os tuítes circulam, podemos definir o microblog também como um suporte que abriga os vários gêneros que podem vir a constituir um tuíte. Como dito no excerto acima, o suporte pode determinar a funcionalidade do gênero, principalmente em contextos tecnológicos, e é justamente o 
que acontece com o Twitter e o tuíte. A plataforma limita a quantidade de espaço que o tuíte apresentará, moldando um gênero para as publicações no site. Não obstante, a necessidade da conexão via internet, definida aqui também como um suporte, possibilita a transgressão do que seria o gênero tuíte, fazendo com que a homepage se transforme em um aglomerado de gêneros diversos, como compreendemos a partir de Silva (2014).

Por fim, julgamos pertinente apontarmos para o conceito de rede social. Ao contrário do que é visto com mais frequência nos dias atuais, tal conceito é muito mais abrangente do que aquele que o senso comum formula, relacionando-o diretamente a aplicativos como o Twitter, Facebook, Instagram, entre outros. Para Recuero (2009), o conceito de rede social compreende um conjunto de atores e conexões, constituído por pessoas, instituições ou grupos, bem como suas respectivas interações ou laços sociais.

Encontramos, então, as características de rede social no Twitter já que as interações no microblog acontecem através de diversos meios. Seja por meio dos próprios tuítes, seja por mensagens diretas para outro usuário, as conexões ocorrem a todo instante e sem obstáculos dentro da ferramenta, fortalecendo assim as redes sociais constituídas. Dessa maneira, seguindo os termos de Recuero (2009), pretendemos analisar padrões de conexão existentes em determinado grupo social a partir das conexões estabelecidas entre os atores selecionados.

A seguir, organizaremos alguns dos conceitos principais acerca do ethos discursivo.

\section{Um olhar sobre o ethos}

Embora a nomenclatura ethos tenha sido adotada anos depois, muitos autores atribuem a Aristóteles o título de precursor do tema. Acredita-se que, já na Retórica (384-322 a.C), Aristóteles refletia sobre a imagem criada por um orador ao mostrar-se ao público. Por não ser o reflexo da realidade e, sim, uma maneira de mostrar-se, é que tal imagem pôde ser considerada uma construção discursiva (SILVA, 2014). Inclusive, o uso frequente da palavra "aparência” demonstra como Aristóteles percebia essa construção. 
Além disso, também foi objetivo de Aristóteles compreender como, a partir da maneira de mostrar-se, determinado orador consegue conquistar um auditório. $\mathrm{O}$ filósofo concluiu, então, que alguns fatores se tornam mais persuasivos para determinados tipos ou grupos de indivíduos em detrimento de outros. Por isso,

\begin{abstract}
a persuasão só é obtida se o auditório constatar no orador o mesmo ethos que vê em si mesmo: persuadir consistirá em fazer passar em seu discurso o ethos característico do auditório, para dar-lhe a impressão de que é um dos seus que se dirige a ele (MAINGUENEAU, 2008a, p. 58).
\end{abstract}

Ademais, além de reunir subsídios para aproximar-se do auditório, para Aristóteles (2005), a imagem elaborada pelo orador também precisa causar uma impressão positiva. Desse modo, o auditório pode construir positivamente o caráter do orador e, consequentemente, confiar nele. Portanto, por meio de seu discurso o orador deve apresentar características necessárias para convencer o auditório sobre o seu caráter.

Tais características são definidas como provas por Aristóteles (1985), sendo elas fundamentais para a arte retórica. Essas provas, por sua vez, são classificadas pelo filósofo em dependentes e independentes. Como o próprio nome já adianta, as provas independentes não dependem do orador e estão relacionadas às testemunhas. Quanto às provas dependentes, há três delas que podem ser utilizadas pelo orador na tentativa de persuasão do auditório, a saber: o ethos (referente ao caráter do orador), o páthos (relacionado às paixões despertadas nos destinatários) e o logos (o discurso em si).

Ainda, para o filósofo, o caráter do orador é o fator mais influente na conquista do auditório. Desse modo, o ethos se destaca como a mais importante das provas dependentes e, para que o sucesso da palavra seja alcançado, o orador precisa também imprimir em seu discurso qualidades como prudência, virtude e benevolência, mesmo que tais características não sejam de fato pertencentes à imagem real dele. Logo, a conquista do auditório será um efeito do próprio discurso.

Ao longo dos anos, a construção da imagem de si foi abordada também por correntes diversas, como pela linguística da enunciação, pela sociologia, pela pragmática e, mais recentemente, pela análise do discurso. Entretanto, como discorre Amossy 
(2005), em alguns momentos, a retórica acabou sendo abandonada, o que acarretou certos deslocamentos na teorização da temática.

No âmbito da linguística da enunciação, por exemplo, é necessário destacar os trabalhos de Émile Benveniste (1999). Em sua teoria, o linguista propõe a noção de quadro figurativo, colocando o eu no centro da enunciação e como um parâmetro que define os fatores essenciais para a enunciação. Além disso, as figuras postuladas por ele, figuras essas que são parceiras e protagonistas da enunciação, são, também, as imagens de si produzidas no/pelo discurso.

Embora ainda sinalize em sua teoria a tentativa do locutor de controlar o próprio dizer, esse não foi o ponto central da teoria do linguista e, mesmo tratando da construção de imagens de si no discurso, Benveniste (1999) não chegou a utilizar, de fato, o termo ethos.

O mesmo acontece nos estudos do sociólogo Erving Goffman. A partir de uma perspectiva interacional, Goffman (1985) teoriza que os locutores, denominados interactantes, exercem influência mútua a partir das imagens de si que constroem no discurso. Tal influência, nesse viés, também pode ser voluntária ou involuntária, e é abordada pelo autor enquanto representação. Assim, o sociólogo desenvolve um quadro de referência para compreender esse processo de representação de si nas mais diversas práticas sociais.

A noção de ethos é finalmente retomada a partir das ideias de Oswald Ducrot. Com a pragmática-semântica, Ducrot (1987) introduz o termo ethos às ciências da linguagem e apresenta um dos mais importantes deslocamentos para a teoria: o sujeito falante real é separado da instância discursiva do locutor, diferente do que acontece nas teorias antecedentes.

Assim, para o estudioso, pouco importa a veracidade do que é dito e, muito menos, se o que é dito se relaciona à personalidade real do locutor. O que é levado em consideração aqui são os recursos utilizados pela instância discursiva do locutor e a aparência e os argumentos mobilizados no discurso na tentativa de conquistar determinado público - o que nem sempre acontece.

Por fim, a partir da década de 1980, a noção de ethos ganhou mais visibilidade nos estudos discursivos com as contribuições de Dominique Maingueneau. A temática vem 
sendo trabalhada pelo linguista, desde então, em diferentes corpora, uma vez que, para ele, o ethos pode se manifestar tanto em situações orais, como se concebia nos estudos retóricos, quanto em textos dos mais diversos gêneros. Ao decorrer deste trabalho, apresentamos mais acerca da teoria de Maingueneau e como ela tem contribuído para a pesquisa nesse âmbito.

Também destacamos aqui a tese de Silva (2014), intitulada Ciberviolência, ethos e gêneros de discurso em comunidades virtuais: o professor como alvo, que defende a existência de um deslocamento de sentido na concepção de ethos. A pesquisadora indica que outros tipos de ethé, comportando-se de maneira contrária ao que Aristóteles prevê, também conquistam a adesão do público. Assim, características consideradas negativas, diferente do que aponta a concepção tradicional de ethos, são igualmente capazes de persuadir e adquirir a confiança de determinados públicos.

Desse modo, a fim de compreender a construção do ethos e, também, o seu deslocamento da concepção tradicional, partiremos de uma perspectiva discursiva baseada em Maingueneau (2008a, 2008b, 2010, 2013, 2015) e com contribuições de Amossy (2005) e Silva (2014).

Inicialmente, precisamos discorrer sobre o processo da adesão, mencionado anteriormente nesta seção. A adesão, portanto, refere-se a uma reação de concordância em relação ao discurso do outro. Logo, para que a adesão ocorra, ainda é preciso que o enunciador apresente marcas discursivas comuns ao seu coenunciador, uma vez que

\footnotetext{
o discurso, através da leitura ou da audição, faz com que o destinatário partilhe de certo movimento do corpo, em um processo de "incorporação" que implica certo "mundo ético", associado a comportamentos esterotípicos. Assim, o "conteúdo" do enunciado suscita a adesão por meio de uma maneira de dizer que é também uma maneira de ser (MAINGUENEAU, 2010, p. 80, grifo nosso).
}

Por conseguinte, também é importante destacar a adesão ideológica. Silva (2014, p. 184) acredita que, "ao curtir algo, o internauta faz uma adesão ideológica e dá mais projeção ao texto". Nesse sentido, entende-se que tanto curtir, quanto retuitar um conteúdo reforça a projeção de determinada publicação, demonstrando que o internauta concorda com o que está presente no enunciado e que, além disso, pretende ajudar a divulgá-lo. Essa conclusão, ainda segundo Silva (2014), parte não apenas dos analistas do 
discurso, como também da justiça, uma vez que já existe punição tanto para os criadores de conteúdos inadequados, quanto para os replicadores.

Estamos cientes de que, a cada dia, novas funções são acrescentadas às diferentes redes sociais. No entanto, pensando especificamente em nosso campo de coleta de dados, o Twitter, constatamos que esse tipo de adesão é ainda mais claro. Não há, até então, uma derivação da opção de curtir, como há no Facebook, por exemplo. Neste último, o internauta pode reagir de maneiras diversas à publicação, demonstrando felicidade, raiva, tristeza etc. No Twitter, por sua vez, a opção de curtir tem uma única função e, além disso, é representada por um ícone de coração, o que reforça a noção de que a curtida, nesse ambiente, está relacionada a certa concordância.

Ademais, entre 2015 e 2016, a opção “retuitar com comentário" ou "tuíte com comentário" ainda não havia sido aplicada à plataforma. Logo, ao retuitar, o usuário apenas "colaria” integralmente o tuíte em seu mural, aderindo e, a depender do tipo de enunciado, incorporando o ethos ali presente.

Sob esse ponto de vista,

Quando curtimos um texto no Feed de Notícias e especialmente num Grupo ao qual nos filiamos e quando esse texto não se dirige especificamente a nós, o funcionamento discursivo pode ser um pouco diferente. Analisar esse caso como apenas sinalização de que leu ou viu o texto é uma interpretação ingênua demais, até porque não somos obrigados a registrar a leitura de tudo que passa aos nossos olhos [...] curtir somente alguns textos, em detrimento dos demais, revela que o leitor compartilha a ideologia materializada [...] Ponderamos ser pouco provável que os internautas cliquem aleatória e imparcialmente no ícone "Curtir" de textos não escritos para eles; por isso, defendemos que o uso dessa ferramenta virtual revela uma adesão ao discurso [...] (SILVA, 2014, p. 184-185, grifo da autora).

Por isso, além do dizer ser legitimado no momento em que é dito e encarnado por um enunciador (MAINGUENEAU, 2013), os discursos, seja ele o discurso violento, como na tese de Silva (2014), ou qualquer outro, no âmbito das redes, é legitimado também a partir da quantidade de pessoas conectadas a um nó ${ }^{3}$, visto que, quanto mais pessoas conectadas, mais ele se torna popular e, assim, passa a ter maior capacidade de influência. $\mathrm{O}$ fato de determinado tipo de discurso conseguir legitimar enunciados,

\footnotetext{
3 É definido por Recuero (2009) como os nós da rede, constituídos pelas pessoas, instituições ou grupos em outras palavras, pelos atores sociais.
} 
reforçando os nós da rede, demonstra que mais e mais sujeitos identificam-se com aqueles discursos (RECUERO, 2009).

Em adição, no movimento de construção da imagem discursiva ocorrerá também um processo de estereotipagem. Isso faz-se necessário para que o locutor tenha as ferramentas adequadas para alcançar seu público. Desse modo, “o orador adapta sua apresentação de si aos esquemas coletivos que ele crê interiorizados e valorizados por seu público-alvo. Ele o faz não somente pelo que diz de sua própria pessoa [...], mas também pelas modalidades de sua enunciação" (AMOSSY, 2005, p. 126).

Em outras palavras, modelos culturalmente fixados são mobilizados como a base para a construção da imagem do locutor. Para tanto, de acordo com Amossy (2005), ao representar seu público, o locutor precisa relacionar determinadas categorias, sejam elas sociais, étnicas, políticas, etc. Por isso, é essencial que o locutor conheça o seu auditório e, a depender da concepção formada, se esforce para se adaptar ao seu alvo.

Além disso, a imagem do locutor será elaborada pelo interlocutor a partir de um conjunto de elementos presentes no discurso que podem aparecer de maneira implícita. Esses elementos estão relacionados, por sua vez, à própria pessoa do locutor e à situação em que ele está envolvido (AMOSSY, 2005).

Considerando os aspectos anteriormente mencionados, chegamos ao conceito de fiador. Essa figura, segundo Maingueneau (2008b), comporta as noções de caráter (características psíquicas) e corporalidade (características físicas) que são empregadas a um determinado enunciador. O fiador constrói-se, então, a partir de representações coletivas que permitem reflexões que remetem a estereótipos. Uma vez que o ethos está atrelado a uma maneira dos indivíduos mostrarem-se em diferentes espaços sociais, o destinatário percebe como o enunciador apoia-se em variadas representações sociais de estereótipos. Por isso, o linguista francês ainda salienta que essas representações podem ser aquelas avaliadas positiva ou negativamente e que, graças à enunciação, podem ser reforçadas ou transformadas.

A função do fiador, para Maingueneau (2008b), é fazer o destinatário ter acesso ao mundo ético. Esse último conceito é constituído por situações estereotípicas relacionadas a comportamentos. A partir do contato do destinatário com o mundo ético presente na enunciação é que a incorporação pode ocorrer. $\mathrm{O}$ autor define, então, a 
incorporação como o movimento de apropriação de um determinado ethos, movimento que se dá a partir da leitura ou escuta de um enunciado.

Há determinadas etapas que auxiliam a compreensão do processo de incorporação do ethos. Nossos referenciais teóricos, Maingueneau (2008b) e Silva (2014), apontam que i) a enunciação elabora certa corporalidade à figura do fiador; ii) ocorre a apropriação do ethos por parte do destinatário e iii) constitui-se um só corpo resultante das incorporações anteriores. Uma comunidade imaginária é constituída também como resultado desse processo, representando assim o grupo daqueles que aderiram a um mesmo discurso.

Durante a enunciação, no entanto, o ethos visado pelo enunciador pode não ser o mesmo ethos elaborado por seu destinatário, o coenunciador. Nesse caso, o cerne do problema se encontra na construção do ethos dito e do ethos mostrado. Ambos, de acordo com Maingueneau (2008a), estão inscritos nos extremos de uma linha contínua. Por esse motivo, não é possível determinar até onde vai o "dito" sugerido e o que foi puramente "mostrado". Dessa maneira, o ethos é efetivo quando é o resultado da convergência dessas e de outras instâncias presentes na enunciação.

Em conclusão, nos embasamos em Maingueneau (2008a) ao olhar para o conceito de ethos híbrido. As diferentes escolhas lexicais, as figuras de linguagem, os discursos anteriores mobilizados, o jogo com os estereótipos etc. contribuem para a elaboração de um ethos que movimenta diferentes categorias de enunciação que, em alguns casos, podem até ser ambíguas. Assim sendo, ressaltamos que a construção de ethé híbridos pode ser melhor compreendida a partir de ethé que não são previstos na concepção tradicional, como veremos no corpus de nossa análise.

\section{Análise dos dados}

Quando nos propomos a analisar o ethos em um ambiente virtual e, em nosso caso, em um microblog, precisamos lançar mão de algumas categorias de análise voltadas para esses tipos de suportes digitais. Maingueneau (2010), ao ponderar sobre o 
ethos em sites de relacionamento, elaborou determinados planos em que o ethos se constrói, a saber: o ethos dito (informações sobre o usuário fornecidas por ele mesmo, dentre elas, o pseudônimo, que pode estar contido tanto no user, quanto no nome de perfil); o ethos discursivo/ethos mostrado (a imagem do enunciador que é elaborada a partir do texto/publicação em si) e o ethos construído a partir das fotos (luz, posição do rosto, edições etc. são elementos que auxiliam na construção desse tipo de ethos).

Seguimos os critérios descritos na Introdução deste trabalho e coletamos as publicações que estão sistematizadas nas tabelas abaixo. A partir das análises que seguem posteriormente, categorizamos nossos dados em ethos de insatisfação e ethos de pessimismo. Vejamos:

Tabela 1: Ethos de insatisfação

\begin{tabular}{|c|c|c|c|c|c|}
\hline $\begin{array}{l}\text { User } \\
\text { (@) }\end{array}$ & $\begin{array}{c}\text { Nome de } \\
\text { perfil }\end{array}$ & Tuíte & $\begin{array}{c}\text { Foto de } \\
\text { perfil }\end{array}$ & $\begin{array}{c}\text { Retuítes e } \\
\text { curtidas }\end{array}$ & Fonte \\
\hline @—_ & & $\begin{array}{l}\text { "tirando beleza } \\
\text { saude e dinheiro o } \\
\text { resto eu tenho tudo } \\
\text { então eu acho que } \\
\text { eu to bem" }\end{array}$ & & $49-29$ & $\begin{array}{l}\text { https://twit } \\
\text { ter.com/feli } \\
\text { pe_barbosa } \\
\text { p/status/65 } \\
\text { 04110287575 } \\
44960\end{array}$ \\
\hline $\begin{array}{l}@ \text { pef } \\
\text { abiod } \\
\text { emel } \\
\text { o }\end{array}$ & $\begin{array}{c}\text { Fábio de } \\
\text { Melo }\end{array}$ & $\begin{array}{c}\text { “Trouxas } \\
\text { Bristô/Cardápio do } \\
\text { dia: } \\
\text { Entrada: Sopinha } \\
\text { de sensatez. } \\
\text { Prato principal: } \\
\text { Risoto de abre o } \\
\text { olho. } \\
\text { Sobremesa: Pudim } \\
\text { de amor próprio.” }\end{array}$ & & $3.897-4.765$ & $\begin{array}{l}\underline{\text { https://twit }} \\
\frac{\text { ter.com/pef }}{\text { abiodemelo }} \\
\text { /status/650 } \\
\underline{27758113310} \\
3104\end{array}$ \\
\hline @ & & $\begin{array}{l}\text { "Você está } \\
\text { decepcionado com } \\
\text { a vida hoje? } \\
\text { Sempre" }\end{array}$ & & o & $\begin{array}{l}\frac{\underline{\text { https://twit }}}{\text { ter.com/du }} \\
\text { uhw/status/ } \\
\frac{6954232749}{48231168}\end{array}$ \\
\hline @ & $\begin{array}{l}\text { Depressivi } \\
\text { ane }\end{array}$ & $\begin{array}{l}\text { “ta td bem só ta } \\
\text { destruida a vida }\end{array}$ & & $\mathrm{O}$ & $\begin{array}{l}\frac{\text { https://twit }}{\text { ter.com/na }} \\
\text { hcoosta }\end{array}$ \\
\hline
\end{tabular}




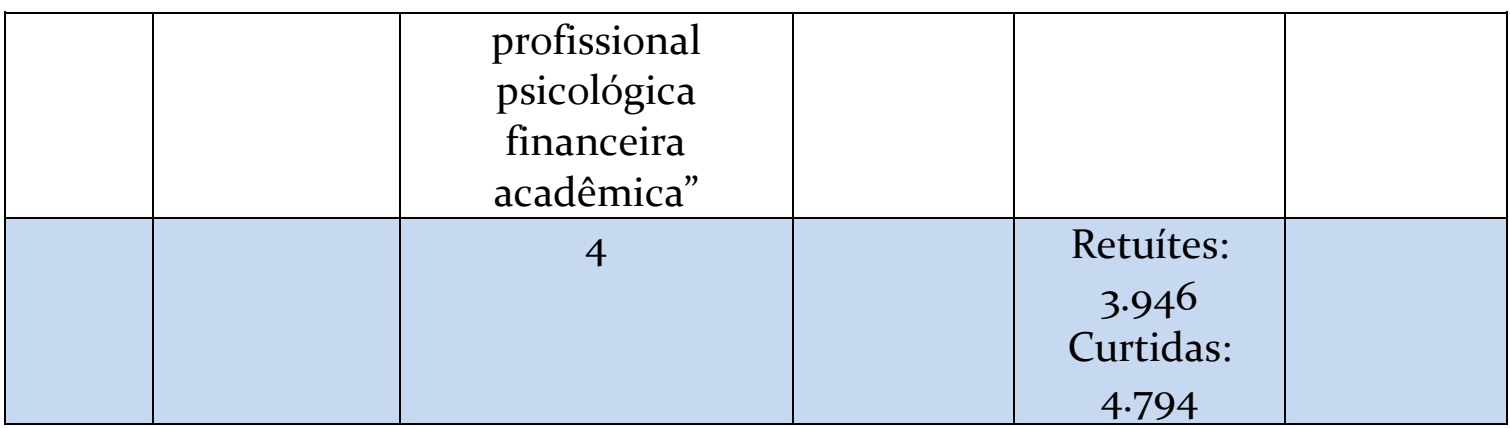

Fonte: Elaborada pela autora

A insatisfação, caracterizada pelo aborrecimento e pelo descontentamento (MICHAELIS, 2016), pode ser vista em nosso corpus a partir dos tuítes apresentados acima. Um destes exemplos é ilustrado pelo tuíte a seguir, publicado pelo Padre Fábio de Melo. Como já analisamos em trabalhos anteriores, o Padre, em sua conta pessoal, constrói um ethos diferente daquele esperado pela maioria de seus leitores. O estereótipo da figura de um líder católico é contrariado em algumas das publicações de Melo e aqui trazemos um exemplo dessa transgressão.

É interessante notar, a princípio, a ação do ethos dito. O user do referido enunciador, @pefabiodemelo, aponta para o papel social exercido por ele a partir da abreviação "pe". Dessa forma, compreendemos que Fábio de Melo não pretende se desvincular, pelo menos não totalmente, da imagem de Padre, imagem pela qual ele se tornou uma figura publicamente conhecida.

Pode ser uma estratégia do próprio enunciador utilizar a abreviação "pe" apenas no user, para facilitar a busca por seu perfil e, por outro lado, não a utilizar no espaço reservado para o nome de perfil, possivelmente numa tentativa de equilibrar a imagem de Padre versus a imagem de um homem comum. 
Figura 1: Ethos de insatisfação em tuíte do Padre Fábio de Melo
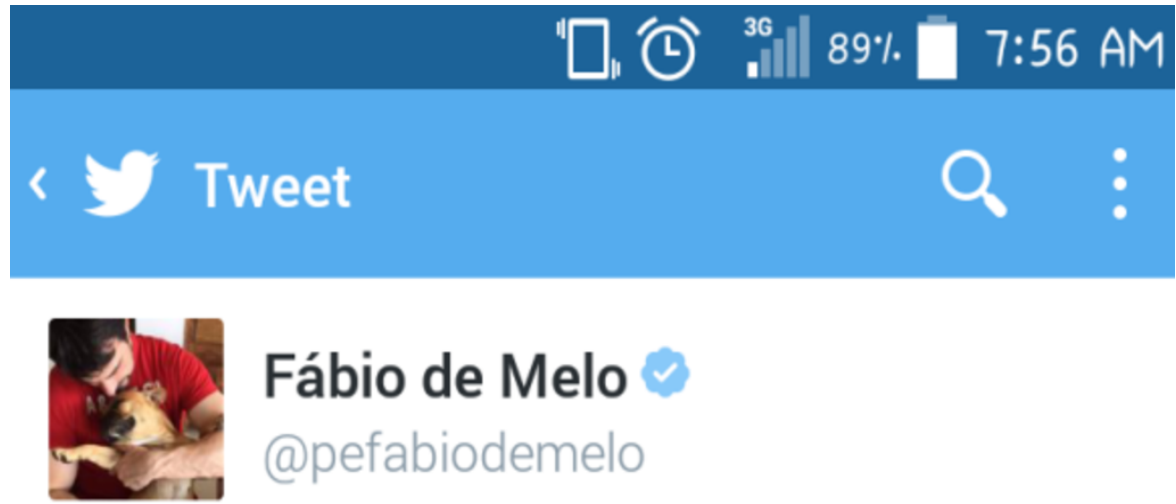

\section{Fábio de Melo}

@pefabiodemelo

TrouxasBistrô/Cardápio do dia:

\section{Entrada: Sopinha de sensatez. \\ Prato principal: Risoto de abre o olho. Sobremesa: Pudim de amor próprio.}

8:53 AM $\cdot 03$ out 15

\subsection{RETWEETS $\mathbf{4 . 7 6 5}$ CURTIRAM}

Fonte: Twitter. Disponível em:

https://twitter.com/pefabiodemelo/status/650277581133103104. Acesso em 03 out 2015

Quanto ao ethos propriamente discursivo, inicialmente vale ressaltar o significado do adjetivo empregado no início do enunciado. Utilizado com grande frequência em diversas variedades linguísticas, trouxa representa um indivíduo que passa constantemente por desilusões e parece não aprender com os erros, voltando a repeti-los. Assim, ao apresentar o cardápio do dia no estabelecimento fictício voltado às pessoas que se identificam com o adjetivo, o enunciador sugere atitudes que possivelmente poderiam fazer com que as desilusões não voltassem a acontecer. 
Como o enunciador faz uso de um fiador e não se coloca diretamente no enunciado, transgredindo o contrato genérico do tuíte, não podemos saber se o cardápio seria proposto para o seu público ou para ele mesmo. Entretanto, se retomarmos os conceitos dos nossos pressupostos teóricos, recordaremos que o enunciador se mostra ao seu público de uma maneira em que esse último se sinta representado pelo primeiro. Logo, o enunciador aproxima-se do público por meio do enunciado, construindo seu ethos discursivo e demonstrando que partilha dos mesmos sentimentos e ideias com o intuito de persuadi-lo e levá-lo a acreditar em seu discurso.

Assim sendo, podemos supor que o fiador do Padre Fábio de Melo também se coloca como trouxa. Desse modo, ainda seguindo a metáfora utilizada no tuíte, a dieta até então adotada não estaria suprindo as necessidades do fiador e, assim, causando o sentimento de insatisfação. Então, ele se coloca na posição de sugerir uma mudança no cardápio oferecido no Trouxas Bistrô em que estariam inclusos a sensatez, a atenção (risoto de abre o olho) e o amor próprio.

Além disso, podemos perceber que o ethos construído pela foto de perfil nessa publicação converge com as demais imagens presentes na Tabela 1. Nessa imagem, Fábio de Melo não mostra totalmente o rosto, inclinando-o para baixo em direção ao cachorro. Nas fotos de perfil das demais publicações, constatamos que nenhum dos outros usuários sorri de fato. A primeira imagem traz um jovem com um sorriso discreto; a terceira também apresenta um sorriso discreto com uma pose que nos remete a alguém tímido; a quarta e última imagem é um pouco mais escura, o que nos impede de visualizar totalmente o rosto da usuária, mas, ainda assim, conseguimos perceber a mão no queixo e as sobrancelhas franzidas.

Um enunciador que pretende construir uma imagem alegre e confiante provavelmente mostraria um sorriso mais evidente e utilizaria uma imagem iluminada que não escondesse o próprio rosto. Afinal, se a intenção é elaborar uma imagem positiva, por que não a exibir no que muitos chamam popularmente de cartão de visitas? O mesmo acontece, então, inversamente. As imagens utilizadas nesses perfis se aproximam do deslocamento da concepção de ethos mencionado anteriormente. Considerados negativos, tais aspectos apresentados nas imagens convergem com o ethos 
discursivo elaborado pela publicação e, além disso, também convergem com o ethos dito (como é o caso do nome de usuário Depressiviane presente na Tabela 1).

Logo, embora estejam presentes apenas 4 ocorrências desta categoria no corpus deste trabalho, constatamos o total de 8.740 adesões somente nestes dados. Portanto, ao retuitar e/ou curtir os tuítes selecionados, os usuários estão também construindo o próprio ethos, uma vez que aderem e incorporam o ethos de insatisfação.

Na tabela seguinte, apresentaremos mais uma categoria elaborada em nosso trabalho. Encontramos o ethos de pessimismo nos tuítes distribuídos a seguir:

Tabela 2: Ethos de pessimismo

\begin{tabular}{|c|c|c|c|c|c|}
\hline $\begin{array}{l}\text { User } \\
\text { (@) }\end{array}$ & $\begin{array}{c}\text { Nome de } \\
\text { usuário }\end{array}$ & Tuíte & $\begin{array}{c}\text { Foto de } \\
\text { perfil }\end{array}$ & $\begin{array}{l}\text { Retuítes e } \\
\text { curtidas }\end{array}$ & Fonte \\
\hline$@$ & $\begin{array}{l}\text { sentoava } \\
\text { raemvcs }\end{array}$ & $\begin{array}{l}\text { "sou tão ansioso que a } \\
\text { pessoa nem me } \\
\text { decepcionou ainda e } \\
\text { eu já to tentando } \\
\text { superar" } \\
\text { "o bom da bad é que } \\
\text { ela passa a madrugada } \\
\text { toda com vc já os } \\
\text { humanos não eles } \\
\text { sempre vão dormir } \\
\text { sem avisar e te deixam } \\
\text { no vácuo" } \\
\text { "tomar um rumo na } \\
\text { vida eu não tomo mas } \\
\text { é cada decisão errada } \\
\text { que eu até me orgulho } \\
\text { de falar 'essa daí foi eu } \\
\text { que tomei" } \\
\text { "e o melhor presente } \\
\text { deus a vida me } \\
\text { ensinou a estragar } \\
\text { tudo que é meu" }\end{array}$ & & $\begin{array}{l}276-273 \\
124-56 \\
82-40\end{array}$ & 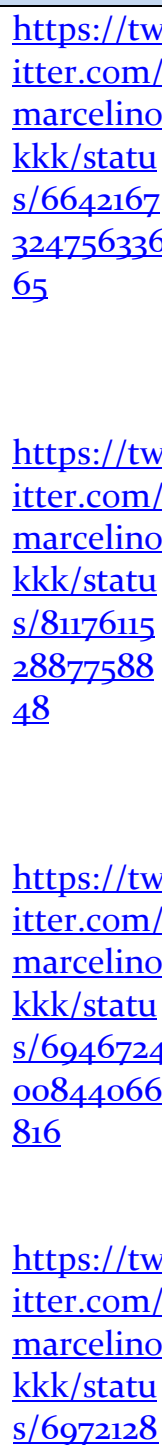 \\
\hline
\end{tabular}




\begin{tabular}{|c|c|c|c|c|}
\hline & & & & $\begin{array}{l}931760087 \\
\text { o4 }\end{array}$ \\
\hline $\begin{array}{l}@ \text { pef } \\
\text { abiod } \\
\text { emel } \\
\text { o }\end{array}$ & $\begin{array}{c}\text { Fábio de } \\
\text { Melo }\end{array}$ & $\begin{array}{c}\text { "O fato de já estar no } \\
\text { Twitter não significa } \\
\text { que eu já esteja pronto } \\
\text { para o convívio } \\
\text { humano" } \\
\text { "Nós na motoquinha } \\
\text { da vida. Eu sou o que } \\
\text { está prestes a ser } \\
\text { lançado no asfalto" }\end{array}$ & $10.700-7 \cdot 310$ & 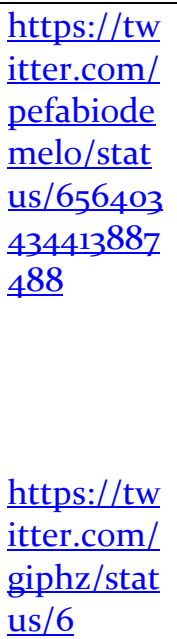 \\
\hline @ & & $\begin{array}{c}\text { "tava no carro falando } \\
\text { dos meus problemas e } \\
\text { o gps disse 'siga em } \\
\text { frente' } \\
\text { Choramos" }\end{array}$ & o & $\begin{array}{l}\text { https://tw } \\
\text { itter.com/ } \\
\text { Jaao Nega } \\
\text { o/status/6 } \\
717272922 \\
\text { ol177088 } \\
\end{array}$ \\
\hline @ & $\begin{array}{l}\text { America } \\
\text { n Psycho }\end{array}$ & $\begin{array}{l}\text { “-Você pratica algum } \\
\text { esporte? } \\
\text { - sim vários } \\
\text { - nossa quais? } \\
\text { - luto com a bad corro } \\
\text { das responsabilidades } \\
\text { nado com as lágrimas } \\
\text { no fundo do poço" }\end{array}$ & $605-452$ & $\begin{array}{l}\text { https://tw } \\
\text { itter.com/ } \\
\text { senhorfili } \\
\text { pe/status/ } \\
67439269 \\
572975820 \\
9\end{array}$ \\
\hline @ - & & $\begin{array}{l}\text { "mas vida que segue } \\
\text { tem otas derrota pela } \\
\text { frente" }\end{array}$ & 2RT & $\begin{array}{l}\frac{\text { https://tw }}{\text { itter.com/ }} \\
\frac{\text { willduarte }}{\text { /status/6 }} \\
\frac{794856341}{39013120}\end{array}$ \\
\hline @ & & $\begin{array}{l}\text { “os que eu magoei em } \\
2015 \text { perdão os que eu } \\
\text { não magoei segue em } \\
\text { frente tem outros ano } \\
\text { pra se decepcionar } \\
\text { comigo" }\end{array}$ & $445-224$ & $\begin{array}{l}\text { https://twi } \\
\text { tter.com/ } \\
\text { pqpvoces/ } \\
\text { status/681 } \\
94740996 \\
\underline{2917888}\end{array}$ \\
\hline & & 10 & $\begin{array}{l}\text { Retuítes: } \\
13.055 \\
\text { Curtidas: } \\
9.328\end{array}$ & \\
\hline
\end{tabular}

Fonte: Elaborada pela autora 
Uma definição para pessimismo seria antecipar o fracasso ou julgar os fatos antecipadamente pelo lado menos favorável, ou, em termos filosóficos, um pensamento metafísico que se caracteriza pelas atitudes ou opiniões negativas em relação aos fatos futuros (MICHAELIS, 2016). Os 10 tuítes alocados nessa categoria têm enunciadores que refletem imagens pessimistas em relação a si mesmos, como no primeiro e no último tuíte da tabela anterior.

As imagens de pessimismo nos tuítes mencionados estão ligadas também a sentimentos como a decepção e a mágoa. Ambos enunciadores antecipam fatos negativos, construindo assim um ethos de pessimismo. A imagem negativa é construída em função do outro no primeiro tuíte e em função de si mesmo no terceiro tuíte da Tabela 2.

As fotos de perfil, por sua vez, seguem quase o mesmo padrão que apontamos nas análises da Tabela 1. Em adição, percebemos que dois usuários não chegam a utilizar fotos pessoais. O primeiro apresenta a imagem de um homem sério que encara a "câmera", convergindo com a imagem violenta presente no nome de usuário sentoavaraemvcs. No entanto, verificamos a elaboração de um ethos híbrido, já que as publicações fazem uso de palavras como "ansioso" e "bad", que fazem parte do mundo ético correspondente ao estereótipo trabalhado.

Em relação à foto de perfil do terceiro usuário da Tabela 2, constatamos que foto, nome de usuário e tuíte também criam um ethos híbrido. Observando a foto de perfil, percebemos um homem de cor azul (possivelmente um extraterrestre), sentado sozinho em um lugar que parece ser fora da órbita terrestre. Quanto ao nome de usuário, “American psycho" (psicopata americano), notamos a elaboração da imagem de um fiador imaginário, que pode se referir à própria personalidade do fiador ou a uma obra literária homônima. Por outro lado, ao analisarmos a publicação, encontramos palavras como "bad", "lágrimas" e "fundo do poço" que, assim como no caso do perfil anterior, também remetem ao estereótipo das pessoas tristes. Deste modo, o leitor que tem acesso a esse perfil provavelmente mobilizará diferentes imagens para elaborar o ethos desse enunciador.

Como já elucidamos anteriormente, o enunciador adapta-se ao seu auditório ao mostrar-se como um deles. Os tuítes das três primeiras linhas da tabela 2 pertencem a 
contas temáticas e/ou públicas que, por meio de suas publicações, buscam agregar temas que agradem aos seguidores, levando-os a compartilhar e ao mesmo tempo divulgar os tuítes da conta, atraindo assim ainda mais seguidores.

Ao produzir enunciados que suscitam um ethos de pessimismo, como é o caso agora, os fiadores dessas contas pretendem satisfazer o seu público. Muitas das contas temáticas, produzindo imagens de tristeza, reproduzem publicações semelhantes ou até mesmo iguais entre si. Talvez esteja aí mais uma constatação: produzir enunciados com ethos de tristeza "dá certo". O estereótipo estimulante citado por Maingueneau (2013), nesses casos, diz respeito ao ethos de tristeza, assim, por meio do processo de incorporação, produzi-los significa suscitar a adesão de um grande número de usuários. Afinal, para o linguista francês, “o poder de persuasão de um discurso consiste em parte em levar o leitor a se identificar com a movimentação de um corpo investido de valores socialmente especificados" (MAINGUENEAU, 2013, p. 108).

Figura 2: Ethos de pessimismo em postagem pessoal
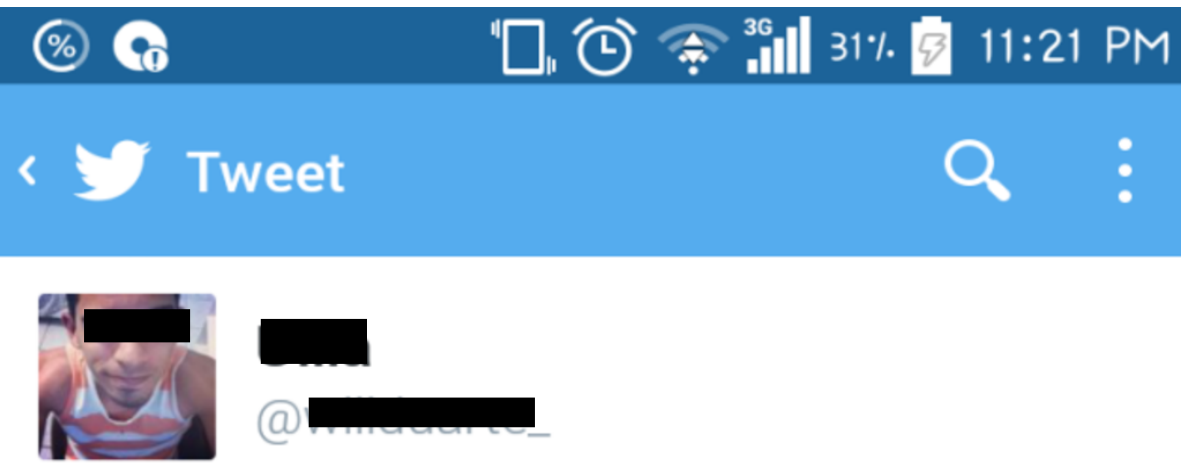

\section{mas vida que segue, tem otas derrota pela frente}

\section{1:16 PM $\cdot 22$ dez 15}

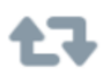

Fonte: $\underline{\text { Twitter }}$ 
É provável, ainda, que a tendência em elaborar ethos de tristeza que estamos constatando aqui tenha surgido a partir de contas pessoais (Figura 2) que, ao conquistar a adesão de determinados usuários, passou a se tornar interessante para as contas temáticas. Também é provável que o caminho inverso tenha sido feito. $\mathrm{O}$ que vale ressaltar é que é possível encontrar as ocorrências que estamos a discutir aqui tanto em perfis com grande alcance quanto naqueles com caráter pessoal.

Por fim, Tapscott (2009) afirma que há um consenso em defender que a Geração Digital se comporta de maneira diferente se comparada às gerações antecedentes. A justificativa está na imersão da geração dos jovens da atualidade em tecnologias digitais, por isso, além de se comportar de outro modo, a geração digital também pensa, aprende e desenvolve características sociais diferentes. Essa última afirmação corrobora, por fim, com nossas constatações. Percebemos que, diferente do que aconteceria sob a ótica de uma concepção tradicional de ethos, ethé construídos a partir de características consideradas negativas suscitam a adesão e, além disso, elaboram uma categoria de ethos até então pouco explorada.

\section{Considerações Finais}

Embora consideradas negativas, as imagens de pessimismo, assim como as de insatisfação, mostraram-se capazes de conquistar um auditório que, além de aderir ao ethos produzido pelos enunciadores, também faz uso dele. As constatações aqui realizadas podem contribuir para a afirmação que vem se tornando tão pertinente: a de que o Twitter é a rede social das pessoas tristes. Um artigo publicado na revista americana Plos One, realizado pela Universidade de Vermont e divulgado em 2011, aponta que, no Twitter, há o uso recorrente de palavras que remetem à tristeza. Segundo os autores, as constatações de felicidade entre as publicações foram muito menores em relação àquelas que apresentaram conteúdo triste. Tal estudo foi citado, ainda em 2011, 
na matéria "De acordo com Twitter, as pessoas estão ficando mais tristes", do site TecMundo, especializado em tecnologia.

Usuários tristes, mas que, ainda assim, conseguem relacionar-se com outros usuários e despertar-lhes a atenção. Embora o caráter triste da rede social possa ser visto como estranho ou até mesmo incômodo por usuários de outros sites, há também aqueles que entendem tais publicações como uma forma de suscitar o riso e o humor. Ao relatar fatos cotidianos, muitos dos usuários acrescentam o tom humorístico, possivelmente, a fim de conseguir interações. Não é por acaso que memes são utilizados frequentemente nas publicações, além das diversas figuras de linguagem que também compõem muitos dos enunciados.

Os números de retuítes e curtidas que apresentamos nas tabelas também nos ajudam a compreender a legitimação do ethos de tristeza. Na Tabela 2, correspondente ao ethos de pessimismo, percebemos que o número de retuítes supera o número de curtidas (Tabela 2: retuítes - 13.055, curtidas - 9.328). Isso pode estar relacionado à própria função do retuíte: ao retuitar, o usuário permitirá que aquele enunciado fale em seu lugar. A publicação também aparecerá em seu próprio perfil, o que comprova a adesão ideológica presente na ação de retuitar. A curtida, por outro lado, já fora mais discreta: nem todos poderiam ver o que um usuário curtia. Para tal, era necessário que um segundo usuário visitasse o perfil em questão e acessasse outra aba disponível no topo do perfil. Atualmente, a timeline apresenta tuítes que foram curtidos pelos seguidores do usuário, mesmo que o dono do tuíte curtido não seja seguido pelo primeiro usuário. Se a coleta de dados houvesse sido realizada após essa mudança, poderíamos cogitar uma mudança significativa no número de curtidas. Entretanto, quando nos voltamos para os números da Tabela 1 (retuítes - 3.946, curtidas - 4.794), notamos que o número de curtidas é maior que o de retuítes. Possivelmente, as constatações do ethos de insatisfação presentes na tabela 1 não levaram à adesão tanto quanto os outros ethé encontrados ou, é provável que as publicações com o ethos de insatisfação não tenham desenvolvido o tom persuasivo necessário para que ocorresse a identificação dos usuários com os discursos.

Em conclusão, entendemos que o "drama", impresso no tom de tristeza encontrado nas publicações, atrai de certo modo sujeitos que desejam tanto desabafar e 
reclamar, quanto rir ou fazer rir e, portanto, adotam como base estereótipos agora cristalizados socialmente. Tal adoção nos leva a refletir sobre quais discursos constroem os determinados estereótipos e, por conseguinte, o que os torna relevantes, como constatamos neste trabalho. Desdobraremos essas reflexões em produções futuras.

\section{Referências}

AMOSSY, R. (Org.). Da noção retórica de ethos à análise do discurso. In: . (Org.). Imagens de si no discurso: a construção do ethos. São Paulo: Contexto, 2005, p. 09-28. ARISTÓTELES. Retórica. Lisboa: Casa da Moeda, 2005. ARISTÓTELES. Arte Retórica e Arte Poética. Trad. de Antônio Pinto de Carvalho. Rio de Janeiro: Editora Tecnoprint, 1985 (Coleção Universidade de Bolso).

BARBOSA, C. W. De acordo com Twitter, as pessoas estão ficando mais tristes. Tecmundo, 2011. Disponível em: https://www.tecmundo.com.br/twitter/16888-deacordo-com-twitter-as-pessoas-estao-ficando-mais-tristes.htm. Acesso em: 13 jul. 2020. BENVENISTE, É. Problemas de Linguística Geral II. Madrid: Siglo Veintiuno, 1999.

BOGDAN, R.; BIKLEN, S. K. Investigação qualitativa em educação: Uma introdução à teoria e aos métodos. Porto: Porto Editora, 1994.

CASTELLS, M. Comunidades virtuais ou sociedade de rede?. In: CASTELLS, M. A galáxia da internet: reflexões sobre a internet, os negócios e a sociedade. Rio de Janeiro: Jorge Zahar Ed., 2003, p. 98-113.

CRESWELL, J. W. Projeto de pesquisa: métodos qualitativo, quantitativo e misto. 2. ed. Porto Alegre: Artmed, 2007.

DODDS, P. S. et al. Temporal Patterns of Happiness and Information in a Global Social Network: Hedonometrics and Twitter. Plos One, 2011.

DUCROT, O. O dizer e o dito. Campinas: Pontes, 1987. 
FERNANDES, J. R.; SAITO, C. L. N. O papel do suporte no gênero propaganda social. In: KRITSCH, R.; DONAT, M. (Orgs.). Seminário de Pesquisa em Ciências Humanas. Londrina: Eduel, 2010.

GOFFMAN, E. A representação do eu na vida cotidiana. Rio de Janeiro: Vozes, 1975.

MAINGUENEAU, D. Discurso e análise do discurso. São Paulo: Parábola Editorial, 2015.

MAINGUENEAU, D. Análise de textos de comunicação. São Paulo: Cortez, 2013, p. 57125.

MAINGUENEAU, D. Ethos - Ethos e apresentação de si nos sites de relacionamento. In: MAINGUENEAU, D. Doze conceitos em análise do discurso. São Paulo: Parábola Editorial, 2010, p. 79-87.

MAINGUENEAU, D. A propósito do ethos. In: MOTTA, A. R.; SALGADO, L. (Orgs.). Ethos discursivo. São Paulo: Contexto, 2008a, p. 11-29.

MAINGUENEAU, D. Cenas da enunciação. São Paulo: Parábola Editorial, 20o8b.

MICHAELIS. Disponível em: http://www.michaelis.uol.com.br. Acesso em: 21 set. 2016. RECUERO, R. Redes sociais na internet. Porto Alegre: Sulina, 2009.

SILVA, M. S. da. Ciberviolência, ethos e gêneros de discurso em comunidades virtuais: o professor como alvo. 2014. Tese (Doutorado em Linguística) - Universidade Federal de Pernambuco, Recife, 2014.

TAPSCOTT, D. Grown up digital - How the Net Generation is Changing Your World. Nova York: McGraw-Hill, 2009.

XAVIER, A. C. Como fazer e apresentar trabalhos científicos em eventos acadêmicos. Recife: Editora Rêspel, 2014. 